\title{
Financial Market Development, Bank Risk with Key Indicators and Their Impact on Financial Performance: A Study from Pakistan
}

\author{
Hafiz Waqas Kamran, Naukhaiz Chaudhry, Muhammad Muzammal Murtaza, Nazish Zafar, \\ Ayesha Yousaf, Huma Nazish \\ Department of Accounting \& Finance, University of Central Punjab, Faisalabad, Pakistan \\ Email: hafizwaqaskamran@gmail.com
}

Received 3 February 2016; accepted 28 March 2016; published 31 March 2016

Copyright (C) 2016 by authors and Scientific Research Publishing Inc.

This work is licensed under the Creative Commons Attribution International License (CC BY). http://creativecommons.org/licenses/by/4.0/

c) $\underset{\text { EY }}{0}$ Open Access

\begin{abstract}
The regulatory outcomes and how the various banks are operating in the economy have their significant impact on the overall banking system and in determining the firmness of financial structure. In the current study analysis, we have conducted this work to examine the relationship between the financial market development, bank risks with key indicators and their ultimate impact on financial performance in the banking sector of Pakistan from 2003 to 2011. For this purpose, panel data analysis has been performed and both the firm specific and country specific factors have been considered. The bank risk is analyzed in two dimensions of bank risk: first is capitalization ratio that measures the total amount of debt in company's capital structure (banks behavior) and second one is TEIR-I capital ratio which is the proxy used to compare the present level of risk based assets in firm's balance sheet. A conceptual model has been developed for this purpose and key findings being made. Stock market development and banking sector development is used to measure the financial market development of the economy. Core findings of the study stated that there exists significant relationship between financial market development in banking sector and financial performance with key indicators.
\end{abstract}

\section{Keywords}

Bank Capitalization, Bank Risk, Financial Market Development, Pakistan

\section{Introduction}

In this paper, we are analyzing the relation between the developments of financial markets in the economy with 
the two dimensional risk factors: like capitalization ratio and the related diversification in the earning capacity is core issue to be observed. We have analyzed the relationship between key factors of banking risk; the capitalization ratio, diversification in the revenue with progression in financial markets. Our aim is to conduct the said analysis through longitudinal data by focusing on the impact of evaluation of progression in financial markets with respect to banking sector behavior. Our Primary focus was on the Pakistani banking industry for the time period of 2003 to 2011, which had captured the major event of global financial crisis. Several research studies have been conducted which have emphasized on financial market development by focusing on cost benefit spectrum. For promoting the domestic investment opportunities, financial market development is contemplation to the growth of the economy as it provides with the better access to finance. The regulatory outcomes and how the various banks are operating in the economy have their significant impact on the overall banking system and in determining the firmness of financial structure.

\section{Literature Review}

The key phenomenon of financial openness leads to the financial market development has been defended by various earlier researchers likewise in the study of [1]-[3]. Both the short term and long term effect of financial market development on the economic growth has been addressed as in the study of [4] who have demonstrated in their study on Argentinean economy that financial liberalization has had a positive and long term effect on economic growth even though in short run it has negative impact as well. At the same point in time [5] have their opinion that the echelon of financial market development reduce up to those firms which are entirely depends upon the internal capital for the corporate level investment opportunities. In addition to above findings the study of [6] have shown that efficient allocation of the resources come into existence through financial market development.

Stiroh \& Rumble did research on bank revenue diversification in developed countries, which is namely the U.S that has documented that a higher reliance on Non-interest activities and lowers risk-adjusted profits. In this paper, they find diversification to be beneficial for Philippine banks. Consistent with Sanya and Wolfe (2011) who study the following Income diversification-performance relationship of listed banks in 11 emerging economies. Philippine banks have a different non-interest income structure. Philippine bank, when they conduct average research they start getting such results The share of trading activities in non-interest income is relatively higher compared with an average U.S. bank. Whereas most of the fee-based income is obtained from traditional bank intermediation activities, trading income is nontraditional as its growth is less correlated with net interest income growth. From a standard portfolio approach, this may indicate that there may be higher diversification benefits from shifts towards trading income activities rather than shifts towards fee-based income activities.

Calderón, C, \& Liu, L. (2003) did a research on financial market development and economic growth. This paper provides an empirical basis for promoting financial and economic development. After the research they get the result in shape of policies which they considered very important. Policy implications were, first, to gain sustainable economic growth, it is desirable to further undertake financial reforms. Second, to take advantage of the positive interaction between financial and economic development, one should liberalize the economy while liberalizing the financial sector. In other words, strategies that promote development in the real economy should also be emphasized. In the same way, some have stated the fact that financial market development impact on economic growth. This paper studies the impact of financial liberalization on economic growth. It contributes to this literature by using these dimensions: an innovative econometric methodology or a unique data set of historical series. It presents power ARCH estimates for Argentina for the period from 1896 to 2000. The main results show that the long-run effect of financial liberalization on economic growth is positive while the short-run effect is negative, albeit substantially smaller. Meanwhile earlier research work also reveals the adverse effect about banking firm's development in the economy. In the study of [7] who have done their investigation by analyzing the sample of 49 countries during the time period of 1994 to 20002. Their key findings were that banking sector development ultimately leads towards the income inequality. Similar findings have been explained by [8].

As in the earlier studies, several steps are available for the measurement of risk preferences and silhouette of uncertainty in banking sector [9]. Normally the core concepts of liquidity, capital adequacy:

- How deposit insurance systems.

- Important aspects of ownership of banks separately.

- $\quad$ Interactively affect market discipline and its impact on banks’ risk-taking incentives. 
They have analyzed how country specific conditions with respect to ownership and governance of banks interact with deposit insurance systems to determine the impact of market 26 discipline on banks' risk-taking. They suggest that the relationship between banks' risk taking and explicit deposit insurance coverage can be described as U-shaped as hypothesized. This is fairly robust although it does not hold for the Z-score. This output in with respect shareholder rights indicates that countries with stronger rights have a lower level of non-performing loans relative to capital.

Some key results indicate that financial liberalization increases bank risk-taking worldwide but through different channels depending on economic development or institutions. In developing countries, financial liberalization negatively impacts bank stability, not as a result of changes in bank competition, but by expanding opportunities to take risk. It is in economically and institutionally developed countries that financial liberalization reduces bank stability through increases in bank competition. We find that capital requirements help reduce the negative impact of financial liberalization on financial stability in both developed and developing countries. We even find that the negative influence of financial liberalization becomes positive in both groups of countries if stringent capital requirements are adopted. However, official supervision and financial transparency have been effective in developing, but not in developed, countries for counteracting the bank risk-taking incentives that are exacerbated by increases in bank competition. Some have examined the impact of financial market development on the extent to which firms have to rely on internal capital for making investments. Using international data from 31 countries for the year 1987-1997, they have concluded that a negative relationship occurs between financial market development and the importance of internal capital.

Financial market developments not only lead towards the economic growth in the country but it also creates numerous opportunities of loan advancement with the increase of demands for various users of funds. A common phenomenon is that for higher loan advancement prospect, banks must have to increase the capitalization ratio as well. However the key question of whether financial market development leads to the lower level of bank capitalization ratios or it has an adverse effect on capitalization ratio of the banks, keeping other things constant is still under debate [10]. They both did the research and examine whether, financial systems facilitate efficient allocation of resources into perspective projects. And after the result, they show that firms in industries with the best growth opportunities use more external finance in financially more developed countries. This was also the result in which they considered robust to controlling for technology determinants of external finance and to choosing different proxies for growth opportunities. They also find that the explanatory power of the technology determinants decreases significantly once growth opportunities are controlled for, which suggests that the often used measures of determinants of external finance are partly driven by growth opportunities. A significant question of whether financial market developments leads to the growth of non-interest income has been addressed by [11]. The fundamental focus was on the idea that financial liberalization unintentionally motivates the financial institutions like banks in order to take the undue or gratuitous amount of risk through non presence of proficient regulation which leads to financial crisis. At the same point in time the contribution of non-interest income to total income of the banks leads towards the higher value of non-diversifiable risk as well [12]. Meanwhile the increase in the level of non-interest income in the overall profit portfolio of the banks originates the volatility in accounting profit [12]. It is promising to facilitate that development of financial markets have an influence on the diversification of bank's return by encouraging the higher intensification of the noninterest income from traditional to non-traditional banking tricks, relative to the growth of the interest income from traditional banking activities. If the bank's revenue diversification precisely corresponds to the level of the bank's hazard, a direct association among development of financial markets and bank revenue diversification contribute positively to the banking system risk element.

\section{Hypothesis and Econometric Equation}

Null hypothesis: Financial performance of financial institutions is not determined by financial development, bank risk and selected key indicators.

Alternative hypothesis: Financial performance of financial institutions is determined by financial development, bank risk and selected key indicators.

The overall equation for the study is as under:

$$
Y_{i t}(\text { Financail Performance })=B 0+B 1 \times 1+B 2 \times 2+B 3 \times 3+B 4 \times 4+B 5 \times 5 \cdots+\epsilon
$$




\subsection{Model of the Study}

In the figure above (Figure 1) the various key indicators of banks performance in terms of country specific and firm specific has been presented. Unobserved factors are also presented from e- 1 to e- 9 which are affecting the model but are not included in the present analysis. The regression weights for these unobserved factors are equal to 01 .

\subsection{Data Source and Research Methodology}

The longitudinal data set covers a 9-year period from 2003 to 2011, with a sample of 17 top banks of Pakistan. The data were taken from the central bank of the country i.e., State bank of Pakistan, various reports. Trade, foreign direct investment FDI, Stock Market Development SMD, Banking sector Development BSD, Size, Liquidity of the banks LIQ, Net Loans NLOAN, Loan Loss Reserves LLR, return on Assets ROA, cost to income ratio CIR, cash to total assets CTA and SNIONN data were obtained both from published annual reports and World Development Indicator WDI database.

Table 1 describes the outcomes of descriptive statistic of the study. Here we can see that the mean value for BSD is maximum which is 25.2955 and ROA has a minimum value of mean which is 0.006013 . The value for the standard deviation is minimum for ROA at 0.02027 which indicates that observations in a data set are more close to mean. The minimum value for majority of the variables is 0 while the maximum value is 128.402 of banks diversification (SNONIN).

Table 2 defines the correlation between various factors of present study. Here we can see that there is significant level of correlation between the various factors like, ROA and SNOIN which is significant at $01 \%$, between ROA and TIER-1 significant at 01\%, ROA and Funding cost FC, ROA and Cash to total assets ratio, between ROA and LIQ and ROA and LLR is also significant at $01 \%$, Besides this correlation is also significant between the other explanatory variables. In order to address either the present level of correlation is problematic or not, we have conducted Variance Inflation Factor Test VIF. The findings of VIF is as under.

In Table 3 the mean VIF is 2.78 which explains the fact that present level of correlation is not problematic, so we have to select all the predictors for the further analysis.

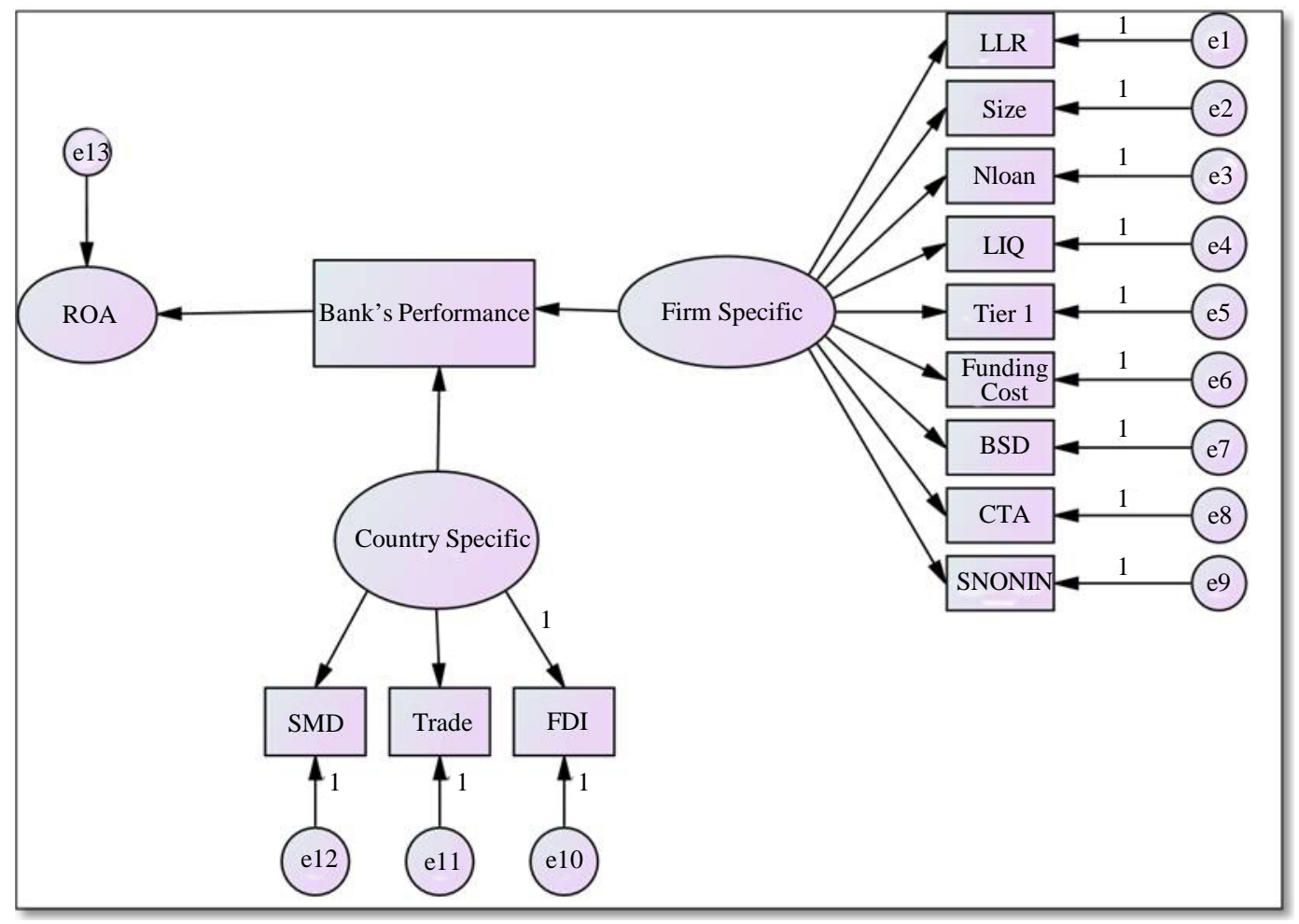

Figure 1. Model of the study (derived from past studies based on personal observation). 
Table 1. Descriptive statistics.

\begin{tabular}{cccccc}
\hline Variable & Obs & Mean & Std. Dev & Min & Max \\
\hline ROA & 153 & 0.006013 & 0.020337 & -0.08 & 0.04 \\
SNONIN & 153 & 21.33078 & 18.98996 & 0 & 128.4 \\
BSD & 153 & 25.2955 & 3.6252 & 18.12 & 28.74 \\
TIERI & 153 & 10.5041 & 11.8809 & 0 & 78.78 \\
F.C & 153 & 0.035163 & 0.03532 & 0 & 0.14 \\
SMD & 153 & 26.8022 & 10.96491 & 13.81 & 46.11 \\
TRADE & 153 & 14.18667 & 1.44955 & 0.59 & 16.72 \\
FDI & 153 & 1.841111 & 1.09268 & 0 & 3.61 \\
SIZE & 153 & 7.4745 & 2.32554 & -0.03 & 9.1 \\
CTA & 153 & 0.08464 & 0.063815 & 0 & 0.42 \\
LIQ & 153 & 0.106928 & 0.04738 & 0 & 0.26 \\
NLOAN & 153 & 0.795686 & 0.047383 & 0 & 0.26 \\
LLR & 153 & 0.076536 & 0.073818 & & 0.4 \\
\hline
\end{tabular}

Table 2. Correlation matrix.

\begin{tabular}{|c|c|c|c|c|c|c|}
\hline & ROA & SNONIN & BSD & TIERI & F.C & SMD \\
\hline ROA & 1 & & & & & \\
\hline \multirow[t]{2}{*}{ SNONIN } & -0.2522 & 1 & & & & \\
\hline & $0.0017^{* * *}$ & & & & & \\
\hline \multirow[t]{2}{*}{ BSD } & 0.0462 & 0.2681 & 1 & & & \\
\hline & 0.5708 & $0.0008^{* * *}$ & & & & \\
\hline \multirow[t]{2}{*}{ TIER1 } & -0.5276 & 0.2763 & -0.1081 & 1 & & \\
\hline & $0.000^{* * *}$ & $0.0005^{* * *}$ & 0.1835 & & & \\
\hline \multirow[t]{2}{*}{ F.C } & -0.2679 & 0.0202 & -0.234 & 0.0985 & 1 & \\
\hline & $0.0008^{* * *}$ & 0.8039 & $0.0036^{* * *}$ & 0.2258 & & \\
\hline \multirow[t]{2}{*}{ SMD } & 0.1282 & 0.1115 & 0.5639 & -0.1026 & -0.1941 & 1 \\
\hline & 0.1143 & 0.1698 & $0.000^{* * *}$ & 0.2067 & $0.0162^{* * *}$ & \\
\hline \multirow[t]{2}{*}{ TRADE } & 0.1375 & -0.0742 & 0.1794 & -0.1253 & -0.4176 & 0.2277 \\
\hline & $0.0902^{*}$ & 0.3619 & $0.0265^{* *}$ & 0.1229 & $0.000^{* * *}$ & 0.0046 \\
\hline \multirow[t]{2}{*}{ FDI } & 0.0238 & 0.2202 & 0.6423 & -0.0075 & 0.0703 & 0.5133 \\
\hline & 0.77 & $0.0062^{* *}$ & $0.000^{* * * *}$ & 0.9268 & 0.3881 & $0.000^{* * *}$ \\
\hline \multirow[t]{2}{*}{ SIZE } & 0.1175 & 0.0361 & 0.0201 & 0.0559 & 0.0312 & 0.052 \\
\hline & 0.148 & 0.6575 & 0.8053 & 0.4927 & 0.7017 & 0.5231 \\
\hline \multirow[t]{2}{*}{ CTA } & -0.232 & 0.2505 & -0.0659 & 0.8418 & -0.0942 & -0.0687 \\
\hline & $0.0039^{* * *}$ & $0.0018^{* * *}$ & 0.4184 & $0^{* * *}$ & 0.2469 & 0.3991 \\
\hline \multirow[t]{2}{*}{ LIQ } & 0.2118 & 0.0995 & 0.2176 & -0.1092 & -0.1446 & 0.169 \\
\hline & $0.0086^{* * *}$ & 0.221 & $0.0069^{* * *}$ & 0.1791 & $0.0746^{*}$ & $0.0368^{* *}$ \\
\hline \multirow[t]{2}{*}{ NLOAN } & -0.0623 & -0.0195 & 0.1824 & 0.0119 & -0.0106 & 0.1889 \\
\hline & 0.4446 & 0.8111 & 0.024 & 0.884 & 0.8962 & 0.0193 \\
\hline \multirow[t]{2}{*}{ LLR } & -0.6053 & 0.3182 & -0.1549 & 0.6792 & 0.0826 & -0.1356 \\
\hline & $0.000^{* * *}$ & $0.0001^{* * *}$ & $0.0559^{*}$ & $0.000^{* * *}$ & 0.31 & $0.0947^{* *}$ \\
\hline
\end{tabular}


Table 3. VIF value.

\begin{tabular}{ccc}
\hline FDI & $\mathbf{6}$ & $\mathbf{0 . 1 6 6 7 6 4}$ \\
TIER & 4.93 & 0.202875 \\
CTA & 4.27 & 0.234092 \\
TRADE & 3.78 & 0.264323 \\
BSD & 3.74 & 0.267553 \\
SMD & 2.25 & 0.444308 \\
LLR & 2.02 & 0.495558 \\
FUNDING COST & 1.49 & 0.670521 \\
SNOINN & 1.3 & 0.77083 \\
LIQ & 1.27 & 0.789171 \\
NLOAN & 1.19 & 0.837148 \\
SIZE & 1.17 & 0.851745 \\
Mean VIF & $\mathbf{2 . 7 8}$ & \\
\hline
\end{tabular}

Table 4 defines the regression outcomes of pooled model. Here we have found that the predictors in the form of banking sector development BSD have a significant impact on Return on Assets ROA. The value of coefficient is negative explaining the fact that one-unit change in the value of banking sector development caused an adverse impact on return on assets. Meanwhile the outcomes of TIER-I capital ratio which is the measuring proxy of bank risk or the risk based assets has also an adverse and significant impact on ROA. The outcomes of SIZE which is the measuring proxy for total assets investment of financial institutions has significant and positive impact on ROA explaining the fact that one-unit change in SIZE, will lead towards the significant and positive change in the value of ROA. The value of coefficient for Loan Loss Reserve has also significant but negative impact on ROA.

Table 5 represents the core findings about goodness of fit of the model. The prob $>$ F value is less than 0.05 which shows that this model is good fit. R-square which shows collective variation caused by the independent variables in the dependent variable is 0.7524 . The value of adjusted R-square is 0.6965 which will increase as the sample size increase. SNONIN, TIER-I, SMD, SIZE, CTA, LLR and Trade has insignificant impact on the ROA. So we can see that out of 12 independent variables, 6 have significant impact on ROA.

By following the approach of fixed effect model, table above shows the outcomes of the key predictors. In Table 6, the coefficients for banking sector development, trade, size, cash to total assets ratio CTA, and Loan Loss Reserve LLR has a significant impact on financial performance of financial institutions.

In Table 7, the core findings have stated the fact that factors like Banking sector development BSD, Trade, TIER-I, SIZE and loan loss reserve LLR has significant impact on Return on Assets under the Random effect model with the key assumption that entities are not correlated with each other. So there is no need to control the effect of entities over a period of study.

In order to compare the result of random effect and fixed effect we have to go for the Hausman test. In Table 8, we have presented the outcomes for fixed and random effect comparison. Here we develop null and alternate hypothesis:

Ho: The difference in coefficient is not systematic;

H1: Difference in co efficient is systematic.

If the results in the form of probability value > chi2 are less than 0.05 then we will accept the H1 stated, the fact that fixed effect is appropriate for the study. If the results are more than 0.05 that shows insignificant effect than we use random effects and we will further go to the Lagrange Multiplier.

The answer is more than 0.05 so we will choose Random effect model.

In Table 9, Lagrange Multiplier test key assumption is that if the value of prob. Is less than 0.05 then random effect is good otherwise pooled regression is acceptable. Here the outcomes are in favor of random effect so we can conclude that random effect is good for the present study. 
Table 4. Pooled regression results.

\begin{tabular}{ccccc}
\hline ROA & Coef. & Std. Err & t & P>|t| \\
\hline SNONIN & -0.0000397 & 0.000065 & -0.61 & 0.542 \\
BSD & -0.001259 & 0.0005781 & -2.18 & $0.031^{* *}$ \\
TIERI & -0.0012651 & 0.0002026 & -6.25 & $0.000^{* * *}$ \\
F.C & -0.0464992 & 0.0374805 & -1.24 & 0.217 \\
SMD & 0.0000364 & 0.0001483 & 0.25 & 0.807 \\
TRADE & 0.0022518 & 0.0014546 & 1.55 & 0.124 \\
FDI & 0.002894 & 0.0024293 & 1.19 & 0.236 \\
SIZE & 0.0010596 & 0.0005051 & 2.1 & $0.038^{* *}$ \\
CTA & 0.207349 & 0.0351087 & 5.91 & $0.000^{* * *}$ \\
LIQ & 0.0309654 & 0.0257531 & 1.2 & 0.231 \\
NLOAN & -0.0009487 & 0.0017891 & -0.53 & 0.597 \\
LLR & -0.1287966 & 0.0208604 & -6.17 & $0.000^{* * *}$ \\
Cons & -0.0027856 & 0.0185494 & -0.15 & 0.881
\end{tabular}

Table 5. LSDVM model coefficents.

\begin{tabular}{|c|c|c|c|c|c|}
\hline Source & SS & Df. & MS & \multicolumn{2}{|c|}{ Number of obs $=153$} \\
\hline \multirow[t]{2}{*}{ Mode } & 0.047301437 & 28 & 0.001689337 & $\mathrm{~F}(28,124)$ & \\
\hline & & & & Prob $>F=$ & \\
\hline \multirow[t]{2}{*}{ Residual } & 0.015566536 & 124 & 0.000125537 & R-squared = & \\
\hline & & & & \multicolumn{2}{|c|}{ Ad. R-squared = 0.6965} \\
\hline Total & 0.062867973 & 152 & 0.000413605 & Root MSE = & \\
\hline \multicolumn{2}{|c|}{ ROA } & Coef. & Std. Err & $\mathbf{T}$ & $\mathbf{P}>|\mathbf{t}|$ \\
\hline \multicolumn{2}{|c|}{ SNONIN } & -0.0001001 & 0.0000675 & -1.48 & 0.141 \\
\hline \multicolumn{2}{|c|}{ BSD } & -0.0011306 & 0.0005004 & -2.26 & $0.026^{* *}$ \\
\hline \multicolumn{2}{|c|}{ TIERI } & -0.0008866 & 0.00023 & -3.85 & $0.000^{* * * *}$ \\
\hline \multicolumn{2}{|c|}{ F.C } & -0.0459603 & 0.0658097 & -0.7 & 0.486 \\
\hline \multicolumn{2}{|c|}{ SMD } & $7.22 \mathrm{E}-06$ & 0.0001272 & 0.06 & 0.955 \\
\hline \multicolumn{2}{|c|}{ TRADE } & 0.0028489 & 0.0013063 & 2.18 & $0.031^{* *}$ \\
\hline \multicolumn{2}{|c|}{ FDI } & 0.0030358 & 0.0020603 & 1.47 & 0.143 \\
\hline \multicolumn{2}{|c|}{ SIZE } & 0.0024288 & 0.0010369 & 2.34 & $0.021^{* *}$ \\
\hline \multicolumn{2}{|c|}{ CTA } & 0.2008387 & 0.0393747 & 5.1 & $0.000^{* * *}$ \\
\hline \multicolumn{2}{|c|}{ LIQ } & 0.0158572 & 0.0322964 & 0.49 & 0.624 \\
\hline \multicolumn{2}{|c|}{ NLOAN } & $5.02 \mathrm{E}-06$ & 0.0017453 & 0 & 0.998 \\
\hline \multicolumn{2}{|c|}{ LLR } & -0.1468872 & 0.0236777 & -6.2 & $0.000^{* * *}$ \\
\hline \multicolumn{2}{|c|}{ _cons. } & -0.015899 & 0.0197627 & -0.8 & 0.423 \\
\hline
\end{tabular}

\section{Conclusion}

This study investigates the impact of financial market development and bank risk with key indicators on bank's profitability in the Pakistan's banks 17 banks for the 2003-20011 periods. There were country specific and firm specific variables having impact on banks performance. Banks with more equity capital, total assets, loans, size in terms of investment in total assets and country level factors i.e., TRADE, FDI and stock market capitalization are perceived to have more safety and such an advantage can be translated into higher profitability of banks. For this purpose, hypotheses have been developed that either the financial market development has 
Table 6. Fixed effect model.

\begin{tabular}{ccccc}
\hline ROA & Coef. & Std. Err & T & P>|t| \\
\hline SNONIN & -0.0001 & $6.75 E-05$ & -1.48 & 0.141 \\
BSD & -0.00113 & 0.0005 & -2.26 & $0.026^{* *}$ \\
TIERI & -0.00089 & 0.00023 & -3.85 & $0.000^{* * *}$ \\
F.C & -0.04596 & 0.06581 & -0.7 & 0.486 \\
SMD & $7.22 \mathrm{E}-06$ & 0.000127 & 0.06 & 0.955 \\
TRADE & 0.002849 & 0.001306 & 2.18 & $0.031^{* *}$ \\
FDI & 0.003036 & 0.00206 & 1.47 & 0.143 \\
SIZE & 0.002429 & 0.001037 & 2.34 & $0.021^{* *}$ \\
CTA & 0.200839 & 0.039375 & 5.1 & $0.000^{* * *}$ \\
LIQ & 0.015857 & 0.032296 & 0.49 & 0.624 \\
NLOAN & $5.02 \mathrm{E}-06$ & 0.001745 & 0 & 0.998 \\
LLR & -0.14689 & 0.023678 & -6.2 & $0.000^{* * *}$ \\
_cons & -0.02413 & 0.019191 & -1.26 & 0.211 \\
\hline
\end{tabular}

Table 7. Random-Effect model.

\begin{tabular}{|c|c|c|c|c|}
\hline ROA & Coef. & Std.Err & $\mathbf{T}$ & $\mathbf{P}>|\mathbf{t}|$ \\
\hline SNONIN & -0.000759 & 0.0000631 & -1.2 & 0.229 \\
\hline BSD & -0.001198 & 0.0004983 & -2.41 & $0.016^{* *}$ \\
\hline TIERI & -0.001052 & 0.0002096 & -5.02 & $0.000^{* * *}$ \\
\hline F.C & -0.035302 & 0.489263 & -0.72 & 0.471 \\
\hline SMD & 0.0000197 & 0.0001266 & 0.16 & 0.876 \\
\hline TRADE & 0.0025478 & 0.0012785 & 1.99 & $0.046^{* *}$ \\
\hline FDI & 0.002905 & 0.0020643 & 1.41 & 0.159 \\
\hline SIZE & 0.0015984 & 0.0007211 & 2.22 & $0.027^{* *}$ \\
\hline CTA & 0.2087073 & 0.0358576 & 5.82 & $0.000^{* * *}$ \\
\hline LIQ & 0.024607 & 0.0278986 & 1.16 & 0.245 \\
\hline NIOAN & 0.0001928 & 0.0016498 & 0.12 & 0.907 \\
\hline LLR & -0.144216 & 0.0210115 & -6.86 & $0.000^{* * *}$ \\
\hline _cons & -0.013981 & 0.0179003 & -0.78 & 0.435 \\
\hline
\end{tabular}

Table 8. Fixed/Random: Hausman test.

\begin{tabular}{ccccc}
\hline & (b) Fixed & (B) random & (b-B) Difference & Sqrt(diag(V_b-V_B)) S.E. \\
\hline SNONIN & $-1 \mathrm{E}-05$ & $-7.59 \mathrm{E}-05$ & -0.0000242 & 0.0000241 \\
BSD & -0.00113 & -0.001199 & 0.0000679 & 0.0000452 \\
TIER1 & -0.00089 & -0.00052 & 0.0001654 & 0.0000948 \\
F.C & -0.04596 & -0.035302 & -0.0106581 & 0.0440129 \\
SMD & $7.22 \mathrm{E}-06$ & $1.97 \mathrm{E}-05$ & -0.0000125 & 0.0000119 \\
TRADE & 0.002849 & 0.002548 & 0.0003011 & 0.0002679 \\
FDI & 0.003036 & 0.002905 & 0.0001308 &. \\
SIZE & 0.002429 & 0.001598 & 0.0008304 & 0.0007452 \\
CTA & 0.200839 & 0.208707 & -0.0078685 & 0.0162664 \\
LIQ & 0.015857 & 0.032461 & -0.0166035 & 0.0162664 \\
Nloan & $5.02 \mathrm{E}-06$ & 0.000193 & -0.0001878 & 0.0005693 \\
LLR & -0.14689 & -0.144216 & -0.0026717 & 0.0109155 \\
\hline
\end{tabular}

Test: Ho: difference in coefficients not systematic; chi2 (12) = (b-B)’[(V_b-V_B $\left.)^{\wedge}(-1)\right](b-B) ; 13.12$; Prob > chi2 = 0.3601; (V_b-V_B is not positive definite). 
Table 9. Testing for random effects: Breusch-Pagan Lagrange multiplier (LM).

chibar $2(01)=36.55$

Prob $>$ chibar $2=0.0000^{* * *}$

significant or no impact on the banks performance in Pakistan. Panel data analysis is conducted for analyzing the impact of financial development market on banks risk. The result shows that there is a significant impact of financial market development with key indicators and risk factor on banking performance, which is good fit.

\section{References}

[1] Chinn, M.D. and Ito, H. (2006) What Matters for Financial Development? Capital Controls, Institutions, and Interactions. Journal of Development Economics, 81, 163-192. http://dx.doi.org/10.1016/j.jdeveco.2005.05.010

[2] Calderón, C. and Liu, L. (2003) The Direction of Causality between Financial Development and Economic Growth. Journal of Development Economics, 72, 321-334. http://dx.doi.org/10.1016/S0304-3878(03)00079-8

[3] Zagorchev, A., Vasconcellos, G. and Bae, Y. (2011) Financial Development, Technology, Growth and Performance: Evidence from the Accession to the EU. Journal of International Financial Markets, Institutions and Money, 21, 743759. http://dx.doi.org/10.1016/j.intfin.2011.05.005

[4] Campos, N.F., Karanasos, M.G. and Tan, B. (2012) Two to Tangle: Financial Development, Political Instability and Economic Growth in Argentina. Journal of Banking and Finance, 36, 290. http://dx.doi.org/10.1016/j.jbankfin.2011.07.011

[5] Islam, S.S. and Mozumdar, A. (2007) Financial Market Development and the Importance of Internal Cash: Evidence from International Data. Journal of Banking \& Finance, 31, 641-658. http://dx.doi.org/10.1016/j.jbankfin.2006.06.009

[6] Bena, J. and Ondko, P. (2012) Financial Development and the Allocation of External Finance. Journal of Empirical Finance, 19, 1-25. http://dx.doi.org/10.1016/j.jempfin.2011.11.002

[7] Gimet, C. and Lagoarde-Segot, T. (2011) A Closer Look at Financial Development and Income Distribution. Journal of Banking \& Finance, 35, 1698-1713. http://dx.doi.org/10.1016/j.jbankfin.2010.11.011

[8] Festić, M., Kavkler, A. and Repina, S. (2011) The Macroeconomic Sources of Systemic Risk in the Banking Sectors of Five New EU Member States. Journal of Banking \& Finance, 35, 310-322. http://dx.doi.org/10.1016/j.jbankfin.2010.08.007

[9] Iannotta, G., Nocera, G. and Sironi, A. (2013) The Impact of Government Ownership on Bank Risk. Journal of Financial Intermediation, 22, 152-176. http://dx.doi.org/10.1016/j.jfi.2012.11.002

[10] Vithessonthi, C. (2014) Financial Markets Development and Bank Risk: Experience from Thailand during 1990-2012. Journal of Multinational Financial Management, 27, 67-88. http://dx.doi.org/10.1016/j.mulfin.2014.05.003

[11] Noy, I. (2004) Financial Liberalization, Prudential Supervision, and the Onset of Banking Crises. Emerging Markets Review, 5, 341-359. http://dx.doi.org/10.1016/j.ememar.2004.05.001

[12] DeLong, G.L. (2001) Stockholder Gains from Focusing versus Diversifying Bank Mergers. Journal of Financial Economics, 59, 221-252. 